\title{
Rusça ve Almanca Temel İfade Cümleleri
}

\section{DR. ÖĞR. ÜYESI KEZIBAN TOPBAŞOĞLU ERAY* - DR. ÖĞR. ÜYESI MEHMET BURAK BÜYÜKTOPÇU**}

Öz

Birden fazla dili aynı anda öğrenmeye çalışmak, dil öğrenicilerinin zaman zaman büyük sorunlarla karşılaşmasına neden olmaktadır. Gerek farklı gramer yapıları gerekse farklı alfabe ve sözdizimsel özellikler bu sorunların temelini oluşturmaktadır. Bu çalışmada, Rusça ve Almancayı aynı anda veya birbirinden yararlanarak öğrenmek isteyen dil öğrenicilerine kolaylık sağlamak amaçlanmış ve her iki dildeki temel ifade cümleleri sözdizimsel, semantik ve morfolojik bağlamda karşılaştırmalı olarak ele alınmıştır. Rusça ve Almancanın farklı dilsel özellikleri olmasına karşın, bazı dilbilgisel kullanımlarda benzerlikler olduğu da görülmüştür. Tüm inceleme sonucunda, çalışmanın çoklu dil öğreniminde faydalı olacağı düşünülmektedir. Çalışmanın, Rusça ve Almancayı ele alması sebebiyle, aynı zamanda karşılaştırmalı dilbilgisi çalışmalarına da katkı sağlayacağı öngörülmektedir.

Anahtar sözcükler: Rusça temel ifade cümleleri, Almanca temel ifade cümleleri, sözdizim, anlambilim, morfoloji

\section{RUSSIAN AND GERMAN BASIC PHRASES}

\section{Abstract}

Trying to learn more than one language at the same time causes language learners to encounter big problems from time to time. Both different grammatical structures and different alphabet and syntactic features form the basis of these problems. In this study, it is aimed to facilitate language learners who want to learn Russian and German at the same time or by making use of each other. The basic phraseological sentences in both languages are discussed comparatively in syntactic, semantic and morphological contexts. Although Russian and German include various linguistic specialities, it has also been observed that there are similarities in some grammatical usages. As a result of the whole examination, it is considered that the study will be beneficial in multilingual learning. Inasmuch as that the study deals with Russian and German, it is predicted that it will also contribute to comparative grammar studies.

Keywords: Russian basic phrases, German basic phrases, syntax, semantics, morphology

\section{GİRiş}

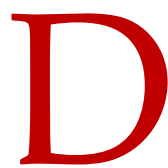
ilin çok farklı, sayısız tanımı yapılabilir. Bunun temel sebebi dilin çeşitli yönleri olmasına ve günümüze kadar dilin tüm yönleriyle ele alınabilecek bir tanımının geliştirilememiş olmasına dayanmaktadır. Genel sözlükte dil “insanların düşündüklerini ve duyduklarını bildirmek için kelimelerle veya işaretlerle yaptıkları anlaşma, lisan, zeban" (Online I) olarak tanımlanmaktadır. Buna karşın Bloomfield (1933) dili “bir alışkanlıklar bütünü” olarak nitelemektedir. Gross'a (1998, s. 19) göre dil “bir kurallar sistemidir

\footnotetext{
* Kafkas Ün. Fen-Edebiyat Fak. Rus Dili ve Edebiyatı, kezibantopbasoglu@outlook.com, orcid: 0000-0002-5943-1230

** Kafkas Ün. Fen-Edebiyat Fak. Alman Dili ve Edebiyat1, buyuktopcuburak@hotmail.com, orcid: 0000-0002-7240-6531 
ve anlaşma aracıdır". Genel dilbilim sözlüğü (İmer vd, 2011, s. 86) ise dili "nedensiz simgelerden oluşan, bildirişimin gerçekleşmesini sağlayan dizge; çok boyutlu kavramlar bütünü" olarak tanımlamaktadır. Dil ile ilgili genel kabul gören bir tanım da Chomsky tarafından yapılmıştır. Chomsky (1965) dili "sınırlı sayıda sözcük ve kuraldan yararlanarak türetilecek sınırsız sayıda kurallı tümceden oluşan bir bütün" olarak tanımlamıştır.

Dil üzerine felsefi soruşturmalar Aristotoles'e kadar uzanmakta, o günden bugüne dilin, insanlığın hayal gücündeki o bağıntılı serüveni de devam etmektedir. Her dönem, durum ve koşulda kabul gören bir gerçek varsa, kuşkusuz, o, insanın dili kullanma, konuşma ve de bildirişme yetisidir.

1960'lara kadar yapılan dilbilim çalışmaları tek bir dile, çoğunlukla İngilizceye, yönelirken, 1966'da Greenberg'in diller üzerine yaptığı tipolojik çalışma bu ağı genişletmiştir. Üreticidönüşümsel dilbilgisi tek bir dili inceleyip belli sonuçlara varırken, tipoloji dil evrenini incelemektedir. Ayrıca dillerin özelliklerini, dil ailelerini yani genetik özelliklerini bölgenin dil üzerine etkileriyle birlikte ele almaktadır. Bunu yaparken de diğerinin aksine birçok dilin ortak yanlarını ve dilbilgisel eğilimlerini deneysel bir kanıta dayanarak sunmaktadır (İkiz, 2019, s. 6).

Nitekim dilleri kendi içerisinde ve daha da yoğun olarak birbirleriyle karşılaştırma istek ve ihtiyacının evveliyatına bakılırsa, bu durum hep dilbilim çalışmalarının odağında durmuştur. ‘Über die Sprache und Weisheit der Indier' eseriyle biçimbilimsel dil sınıflandırmasının ilk adımlarını attığı bilinen Friedrich Schlegel (Meçkovskaya, 2003, s. 17-18) Avrupa dillerini Sanskrit ile karşılaştırarak gramer benzerliklerini ortaya çıkarmaya çalışmış, söz konusu çalışmada bazı morfolojik unsurları dikkate almaksızın bükümlü dillerin gramer açısından diğer dillerden daha sağlam ve daha zengin olduğuna inanmıştır (Shakhin, 2009, s. 3; Reformatski, 1997, s. 444).

Bugün dünya üzerinde konuşan sayısı sınırlı olan yerel dillerle de birlikte yaklaşık 7000 civarı dilin konuşulduğu düşünülmektedir. Henüz dilbilimsel açıdan incelenememiş bölgeler de hesaba katıldığında çok daha fazlasından söz edilebilir. 'Hint-Avrupa, konuşur sayısı bakımından en kalabalık dil ailesidir. Rusça, Bulgarca, Sırpça, Hırvatça, Boşnakça, Lehçe, Makedonca vs. HintAvrupa dillerinin Genel Slav kolunu oluşturmaktadır. Bu dillerden Rusça, Beyaz Rusça ve Ukrayna dili Doğu Slavcayı; Bulgarca, Sırpça, Hırvatça ve Boşnakça Güney Slavcayı; Lehçe, Çekçe ve Slovakça ise Batı Slavcayı temsil etmektedir (Eker, 2009, s. 70). 11 ayrı dil grubu içerisinde incelenen bu dil ailesinde WALS verilerine göre 176 dil vardır (Online II). Almanca ise HintAvrupa dil ailesinin Avrupa kanadının Cermen dilleri sınıfına girmektedir. Ayrıca Avrupa Birliği'nin resmi dillerinden biri de olan Almancanın bugün yaklaşık 150 milyon kişi tarafından konuşulduğu tahmin edilmektedir.

Farklı alfabesi, çok kurallı gramer yapısı ve zengin kelime hazinesiyle öne çıkan Rusça, dolayısıyla, dünyanın çok konuşulan dilleri arasındadır. Geçmişten günümüze kat ettiği yol uzundur; bugün gelinen noktada ise Çağdaş Rus Dili, onu diğer dünya dillerinden ayıran bir dizi özelliğe sahip olduğu gibi, ifade zenginliği açısından da son derece dikkat çekicidir. Dil-düşünceifade ekseninde bakıldığında birbirinden farklı parametreler açığa çıkmakta, bu dili konuşanları ve ekseriya öğrenme sürecinde olanları bir hayli zorlu, bir o kadar da keyifli soruşturmalara yönlendirmektedir. İncelemeye esas Almanca ve Rusçanın gerek farklı alfabe ile oluşturulması 
gerekse dilbilgisel ve dilbilimsel açıdan farklılıklar barındırması dil öğrenicilerinde de güçlükler oluşturmaktadır. Bu noktada, çalışmada her iki dil arasındaki benzerlik ve farklılıkların ortaya konması ve dil öğrenicilerine her iki dile daha kolay hâkim olabilme kolaylı̆̆ını sağlamak amaçlanmıştır.

Diller, morfolojik tipoloji açısından doğrusal bir ölçekteki yerlerine göre yalınlayan/tek heceli (isolating/isolierend)> ekleyen (agglutinating/agglutinierend)> çekimleyen/ bükümleyen (inflectional/flektierend) (Velupillai, 2012, s. 96) şeklinde incelenmektedir ve morfolojik tipoloji noktasında değerlendirildiğinde Rusça ve Almanca bükümlü dillerdir; çekimleri vardır. Rusça ayrıca sentetik bir dil olarak da öne çıkmakta, sözcüklerin leksik anlamlarıyla dilbilgisel anlamlarını birleştirmektedir. Rusçada dilin en belirgin 10 ögesi kendini gösterir: İsim, sıfat, sayı, zamir, fiil, zarf, edat, bağlaç, (kiplik) parçacık ve ünlem.

\section{RUSÇADA VE ALMANCADA ПРЕДЯОЖЕНИЕ/SATZ/CÜMLE KAVRAMI VE} ÇEŞİTLERİ

Cümleye dair en yaygın ve de benimsenen tanım, Aristo mantığına kadar giden, bilinen (Thema/konu)- bilinmeyen (Rhema/yorum) karşıtlığına dayanan geleneksel dilbilgisinin yaklaşımıdır. Konu ve yorum kavramları metindilbilimde "metnin anlam örgüsünü oluşturan, metnin konusunu düzenleyen, tümceler arasındaki semantik ve sentaktik ilişkileri kuran etkenler" (Toklu, 2011: 135) olarak tanımlanmaktadır. Buna göre tümce yalın bir ad (özneden) ve çekimli bir eylem (yüklem) ile varsa düz tümleç ve dolaylı tümleçlerinden oluşur (Darancık ve Balcı, 2017, s. 87).

Cümlenin dilsel bir kategori olarak bütünlüğü, dilbilgisel, anlambilimsel, iletişimsel olmak üzere üç yönün birliğinde kendini göstermektedir. Bununla birlikte cümle, gerçeklik, soru ve irade/istek/emir ifadesi içererek bir düşünceyi şekillendirmeye, ifade etmeye ve iletmeye yardımcı olan dilin gramer birimidir (Река разлилась/ der Fluss ist übergelaufen-nehir taştı; Былл весна/ Es war Frühling-ilkbahardl; День бblл menльйl es war ein heißer Tag-sıcak bir gündü; Я cmyderm/Ich bin ein Student/eine Studentin- ben öğrenciyim; За стеной тихо играли на скрипке/ Sie spielten Violine ruhig hinter der Wand-duvarın arkasında sessizce keman çalıyorlardı ve benzeri) (Lekant, 2004, s. 5-6).

Rusça ve Almancada cümleler yapılarına ve amaçlarına göre sinıflandırılmaktadır. Yapısal açıdan basit (npocmbıleinfach) ve bileşik (сложные/zusammengesetzt) olarak kategorize olan cümleler, amaç noktasında da üç başlık altında incelenmektedir: Soru (вonpocumesbHbıe/Frage), anlatı (повествовательные/Aussage) ve ünlem/emir (nобудительные/Imperativ). Soru cümlesi, anlaşılacağı üzere, soru barındırmakta ve cümle sonunda soru işareti yerleşmektedir: СКолькo тебе ^ет? / Wie alt bist du?- Kaç yaşındasın? Anlatı cümleleri herhangi bir nesne ya da canlı varlığa yönelik bilgi içermekte ve nokta ile sonlanmaktadır: Hаступил ^етний вечер./ Der Sommerabend ist gekommen.- Yaz akşamı geldi. Ünlem cümlelerinde ise belirli bir eylemin gerçeklemesine yönelik emir, istek, yasak, öğüt vb. anlamlarda 'iti'(побуждение) kendini göstermektedir: Прочь $c$ dopozu!/Geh mir aus dem Weg! -Yolumdan çekil! Söz konusu cümlelerin sonuna, ifadenin devam edeceğini ya da konuşmada bir ara, bir duraklama gerektiğini göstermek için birden fazla nokta yerleşebilir: Закрыьвай глаза и спи... Отлично... (Çehov, 1889) Gözlerini kapa ve uуи...Harika... 
Almancada bu kullanım söz konusu değildir. Cümleler devam niteliği taşısa da emir cümlesinden sonra cümlenin sonlandığını belirtmek için ünlem işareti getirilmeli ve sonraki cümle ayrı olarak başlamalıdır. Yapı ve amaç bakımından yukarıdaki şekilde sınıflandırılan cümleler anlam açısından değerlendirildiğinde ise olumlu (утвердительные/positiv) ve olumsuz (отрицุательные/negativ) olarak kategorize edilebilir. Cümle içeriği ile cümlenin öğeleri arasındaki uyum olumlu cümleye, kimi işaret ve belirleyiciler vasitasıyla bu tip bir uyumun söz konusu olmadığı yapılar ise olumsuz cümleye işaret etmektedir. Çalışma içerisinde özellikle odağa alınan olumlu ve olumsuz cümle yapılarında fiil kipleri ve kiplik (kipsellik) ayrıca önemlidir.

\subsection{Rusça ve Almancada Простье предложения/ Einfacher Satz/ Basit Cümleler}

Простое предложение/Einfacher Satz (basit cümle): Basit bir cümle, dilbilgisel olarak oluşturulmuş kelimelerin birleşimidir; betimlenen durumun gerçekliğini veya gerçek olmayışını (olasılık, arzu edilirlik veya gereklilik) yansıtır; konuşmacının bu duruma karşı tutumunu aktarır; belirli bir anlam ve tonlama bütünlügüne sahiptir. Cümlenin yapısında biçimsel, anlamsal ve iletişimsel yönler olduğu gibi, cümlenin kuruluşunda da birincil ve ikincil öğeler yer alabilir. Cümlenin anlamsal (semantik) organizasyonu, öznenin (eylemin üreticisi veya durumun taşıyıcısı), yüklemin (eylemi veya durumu işaretleyen gösterge) ve nesnenin etkileşimi ile belirlenir. Cümlenin iletişimsel organizasyonu belirli bir sözcük düzeni yardımıyla oluşturulur: tema ve rhema oranı (Glazunova, 2011, s. 126). Almancada ise, sadece bir çekimli eylemle kurulan ve sadece bir yargı içeren cümleler basit cümle olarak adlandırılmaktadır (Zengin, 2007, s. 356). Helbig ve Buscha ise, Almanca basit cümleyi öncelikle genel olarak tanımlamakta ve şöyle ifade etmektedir:

Yüklemler değerlikleri sayesinde cümlelerde zorunlu ögelerle (fiilin konum dizgesi için belirlenen ve bulunması zorunlu olan) doldurulması gereken ve cümlede bulunması tercihe dayalı ögelerle doldurulabilecek olan boş konumlar açarlar. Zorunlu ve tercihe dayalı eylemler dışında cümlede serbest bildirişim ögeleri de bulunabilir.

(Helbig\&Buscha, 2000, s. 232)

Örnek: Hans arbeitet seit Jahren in Berlin./ Hans yıllardır Berlin'de çalışıyor.

Tanımdan hareketle örnek cümlede yüklemin değerliğine bağlı olarak bulunması gereken öge özne olarak ortaya çıkmaktadır. Ancak cümlede bulunması isteğe bağlı ögeler de vardır. Hans'ın nerede ve ne kadar süredir çalıştığı sorusunun cevabı eylemin değerliği bakımından konuşmacının isteği ya da doğrudan bu bilgiyi edinmek isteyen göndericinin talebiyle ilgili olmakla birlikte, temel ifade gerçekleştirilirken bu sorular aktarıcıya doğrudan yöneltilmediği sürece seit Jahren/yıllardır ve in Berlin/Berlin'de söz öbekleri cümleden çıkarılabilir. Basit cümlelerin bu özelliği Thema/Rhema (Konu/Yorum) karşılaştırması sayesinde daha kolay anlaşılabilir.

Tema (Konu), dinleyicinin önceden bildiği bilgileri ifade etmekle birlikte, kural olarak cümlede öncelikli olarak yer alır; Rhema (Yorum) ise, cümle içerisinde herhangi bir bilgiye ulaşmak adına sorulan sorunun cevabı gibi henüz konuşma veya bildirişme sırasında öğrenilen yeni bilgileri aktarmaktadır. Örneğin, Oн yexaл cezodнs/Er ist heute weggegangen- O, bugün gitti (ayrildı), cümlesinde Kогда он yexas?/Wann ist er weggegangen? - Ne zaman gitti (ayrlldı)? sorusunu 
cevaplarız; tema (bilinen/ konu) -OH yexas/Er ist weggegangen; rhema (bilinmeyen/ yorum)сегодня/heute.

Basit cümleler, dilin gramer yapısının başında gelen oluşumlardandır. Basit cümle modelinde, bir cümle oluşturmak için gereken en az bir ögeden oluşan somut bir durumun olması yeterlidir. Sadece tek bir öge bile olsa, cümle kavramı oluşmuş demektir (Bak, 2020, s. 1838). Rusçada basit cümleler temel ögesinin sayısına göre tek ögeli (односоставные) ve iki ögeli (двусоставныле) olarak ayrılmaktadır. Tek ögeli cümleler, özne veyahut yüklem formunda tek bir temel ögeye sahip cümlelerdir. Bu cümleler kendi içinde, определённо-личные/bestimmt (belirliözneli), неопределённо-личные/unbestimmt (belirsiz- özneli), обобщённо-личные (genel özneli) безличные (ӧznesiz), инфинитивные (mastar) ve номинативныеl именные (isim cümlesi) olarak ayrılmaktadır. İki öğeli cümlelerde ise, cümlenin her iki ögesi olan özne ve yüklem bulunmaktadır: Сохнйе встаёm- gün/güneş doğuyor. Almancada ise temel cümle, temel yargıyı içeren ve cümlenin öznesine göre çekilen yüklemi ikinci sırada olan cümledir. Almanca temel ifade cümlesinde sırasıyla özne, yüklem, nesne ve varsa belirteçler vs. kullanılır. Bu nedenle Almanca temel ifade cümlelerinde öge dizilişi dikkate alındığında Almanca temel cümle yapısının özne, yüklem, nesne, ÖYN (SVO) şeklinde olduğu görülmektedir. Ancak Almancada özne her zaman ilk sirada olmayabilir. Rusça temel cümle yapısında da ögelerin dizilişi benzer şekilde olmakla birlikte, Almancada olduğu gibi öznenin yeri noktasında bir yaptırım söz konusu değildir: Сmyденm не понимает предложение/Предложение студент не понимает- ̈̈̆renci cümleyi anlamıyor. Almancada cümle yükleminin ikinci sırada olması şartıyla cümle, vurgulanmak istenen nesne ya da belirteç ile de başlayabilir. Örneğin, Der Schüler versteht den Satz nicht/ Öğrenci cümleyi anlamıyor yerine Den Satz versteht der Schüler nicht şeklinde de kullanım mümkündür. Ancak birinci cümlede vurgunun özne olan öğrencide olduğunu, ikinci cümlede ise cümlenin nesnesi olan cümlede olduğunu unutmamak gerekir. Ancak Almancada Rusçada olduğu gibi tek ögeli cümleden bahsetmek pek söz konusu olamamakla birlikte bu kullanıma sadece emir cümlelerinde (Imperativ) rastlandığını söylemek yerinde olacaktır. Örneğin, Komm!/Gel!, Mach!/Yap! gibi emir cümlelerinde tek ögeli kullanım olmakla birlikte günlük konuşma Almancasında da bir soru cümlesine verilen cevaplar kendinden önceki soruya bir bağlantı (Deixis) oluşturması şartıyla tek ögeli oluşturulabilir. Örneğin, Wer ist gekommen?/Kim geldi? sorusuna cevap verilirken -Ahmet şeklinde cevap verildiğinde gelen kişinin Ahmet olduğu anlaşılmaktadır. Ancak bu kullanımın yazı diline aktarımında bir tam cümle (Vollsatz) oluşturma zorunluluğunu da unutmamak gerekir.

Almanca Imperativ yapılarındaki söz konusu durum Rusçada da benzer niteliktedir. Fiilin Imperativ formuyla açı̆̆a çıkan emir anlamı ve sözü edilen tek öğeli yapının (C^ymaŭ!/Her! Dinle!) yanında, kimi zaman, özellikle de emir- komuta ifadelerinde kesin emir ve yasak gibi kategorik anlamlara eşlik eden herhangi bir yapı bulunmaksızın fiillerin çekimsiz (mastar) formlarıyla açığa çıkmaktadır: Moภyamı!/ Schweige! Sus!

\subsection{Rusçada Tek Ögeli Cümleler (Односоставнье предложения)}

Yukarıda Rusça basit cümlelerin öge sayısına göre sınıflandırıldığından ve iki temel ögeden (özne veya yüklem) yalnızca birine sahip olan cümlelere tek ögeli cümle adı verildiğinden 
bahsedilmişti. Almancada cümle türleri ele alındığında tür olarak tek ögeli/çok ögeli cümleler şeklinde bir ayrım yapmak söz konusu değildir. Ancak Rusçada olduğu gibi fiilin değerliğine sadece öznenin eşlik ettiği cümle kullanımı da Almancada yaygındır. Çalışma içerisinden ayrıca ele alınacak olan fiil ve isim soylu yüklem/ cümleler (isim ve fiil cümleleri), tek öğeli cümlelerdeki öznenin niteliği noktasında yapılacak bir değerlendirme için ayrıca önemlidir:

1.2.1 Определённо-дичные предложения (Belirli- Özneli Cümleler): Temel öğesi yüklem olan ve eylemin belirli bir şahıs tarafından gerçekleştirildiğini ifade eden tek öğeli cümlelerdir. Şimdiki zaman veya gelecek zaman planında 1. ya da 2. tekil şahıs formları ve emir kipi (imperativ) formlariyla da ifade edilmektedir:

Скоро приду- yakında geleceğim. Когда принесёшь мне книгу? - Kitabr bana ne zaman getiriyorsun? Пойдёте в кино? Sinemaya gidiyor musunuz? Израйme- Oynayını! Burada özne ya da şahıs sözlü olarak adlandırılmamış, fiilin şahıs ekleriyle işaretlenmiştir. Bu noktada şahıs zamirlerinin kullanımı gerekli değildir; fakat şöyle bir varyasyon da mümkündür: Я cкopo nридyben yakında geliyorum. Когда тыл принесёшь мне книгу? sen kitabı bana nе zaman getiriyorsun? Bы пойдёте в кино? siz sinemaya gidecek misiniz? Böylesi durumlarda cümle iki öğeli (bileşenli) yapıya dönüşmektedir (Kalyuta, 2010, s. 23). Yukarıda belirtildiği gibi Almancada her ne kadar yüklem özneye göre çekimlense de öznesi olmayan bir cümle kurgusu mümkün değildir. Bu sebeple Almancada tek ögeli cümlelerin sadece 2. tekil şahıs emir kipinde ve bazen 2. çoğul şahıs emir kipinde kullanıldığını unutmamak gerekir.

1.2.2 Неопределённо-личные предложения (Belirsiz/ Belgisiz- Özneli/ Es Adıllı Cümleler): Temel öğesi yüklem olan ve eylemin belirsiz bir şahıs tarafından gerçekleştirildiğini ifade eden tek öğeli cümlelerdir. Yüklem şimdiki zaman ve gelecek zaman planında 3. çoğul şahıs formu veya bildirme kipinin (изъявительное наклонение) geçтіş zaman planında çоğul formlarıla ifade edilmektedir: Нам привезут книги- kitaplar bize getirilecek; Тебе звонят с работьseni işten arıyorlar. Yüklem isim ya da fiil soylu olabilir. İsim soylu yüklemler kısa sıfatlarla ifade edileceği gibi, bu noktada fiilin kip, zaman, şahıs, hatta nicelik kategorisine yönelik anlamlar da açı̆̆a çıabilir: Almancada ise, bazı fiillerin bir özne gerektirdiği durumlarda belirsiz özneli cümleler zorunlu/obligatorisch es öznesi ile yapılmaktadır. Burada da öznenin belirsiz olduğunu söylemek mümkündür. Ancak bu tür kullanımlarda es öznesi hem nominativ/yalın hem de akkusativ/-i hali durumlarında görülebilir. Örneğin bir hava durumundan bahsedilirken, 3. tekil şahıs zamiri anlamı dışında kullanılan es nominativ halde cümlede yer alır.

Örn: Es regnet/yă̆mur yă̆ıyor; Es ist heute windig/bugün hava rüzgârlı

Ayrıca bir durumu nitelemek amacıyla akkusativ/-i hali olarak da Almanca cümlelerde yer alabilir.

Örn: Ich lege es darauf an, dass ich vom Lehrer bestraft werde/öğretmen tarafından cezalandırılmayı göze alıorum.

1.2.3 Обобщённо-дичные предложения (Genel-Özneli /Şahıslı Cümleler): Temel öğesi yüklem olan ve eylemin geniş şahıs yelpazesi içinde herhangi bir kişi ya da kişiler tarafından gerçekleştirildiğini ifade eden tek öğeli cümlelerdir. Söz konusu genel şahıs bakış açısından kaynaklı olarak bu tip cümleler deyim ve atasözlerinde sıklıkla karşımıza çıkmaktadır. Yüklem, 
bildirme (изъявительное наклонение) vеуа emir kipinin (повелительное наклонение) 2. tekil şаһis formlarıyla ve 1. ve 3. çoğul şahıs formlarıyla ifade edilmektedir. Sıklıkla atasözü gibi anonim yapılarda karşımıza çıkan bu cümleler için belirgin, somut bir zaman diliminden söz edilemez: Семь раз отмерь- один отрежь- yedi kez ölç, bir kez kes. Almancada ise, bu tip deyimsel ifadeler genellikle fiilin mastar halinden yararlanılarak yapılmaktadır: mit jemandem unter vier Augen sprechen/birisiyle baş başa-özel görüşmek; die Finger von etwas lassen/bir şeyden elini çekmek. Ancak bu türden ifadeler bir ifade cümlesine dönüştürülürken yine özne ve özneye göre çekimlenmiş fiil cümlede yerini alır ve neredeyse tüm zaman türlerinde bir tam ifade cümlesi olarak kurulabilirler. Ayrıca Almancada bu tür deyimsel yapıların emir kipinde kullanımları da mevcuttur.

Örn: Ich habe mit ihm unter vier Augen gesprochen/onunla baş başa/özel konuştum.

Sprich mit mir unter vier Augen!/Benimle özel konuş!

Lass die Finger von meinem Buch!/Kitabımdan elini çek!

Sie hat die Finger von meinem Pommes gelassen/ Elini benim patates kızartmamdan çekti.

1.2.4 Бездичные предложения (Öznesiz Cümleler): Eylemi gerçekleştiren aktif bir özneye sahip olmayan, tek bir temel öğe (yüklem) bulunduran cümlelerdir. Eylem herhangi bir şahsa veya eylemciye bağlı olmaksızın kendi kendine ya da dışarıdan gelen bir etkiyle gelişebilir. Bu tip cümlelerde yüklemi ifade edebilecek farklı dilbilgisel araçlar vardır. Öznesiz cümlelerde yüklemin ifade araçları öznesiz fiiller, öznesiz anlamı içinde barındıran fiiller, fiillerin belgisiz /belirsiz formları, zarflar, edilgen ortaçların kısa formları vb. olabilir. Öznesiz cümle yapıları diğer tek öğeli cümlelere kıyasla çok çeşitli formlara sahip olabilir. Ancak yukarıda da bahsedildiği gibi Almancada öznesiz cümlelerle sadece 2. tekil şahıs emir cümlelerinde karşılaşılmakta ancak temel ifade cümlelerinde, cümlede özne görünümünde olsa da zorunlu olarak özne görevi olan bir es bulunmaktadır. Bir istisna da bazı kalıplaşmış cümle türlerinde görülmektedir. Örneğin tam cümle hali Es tut mir leid!/Üzgünüm ya da Es tut mir weh!/A Ağrlyor olan cümle bazen de Tut mir Leid/üzgünüm ya da tut mir weh!/ağrryor olarak kullanılabilmektedir.

Semantik alanı değerlendirildiğinde öznesiz cümleler (безличные предложения) şи anlamlara karşılık gelebilir (Online III):

$>$ Doğadaki durumlar, olaylar: Mopocum/Es nieselt- yă̆mur çiseliyor. Холоднo/Es ist kaltsoğuk, Очень жарко/Es ist sehr heiß-çok sıcak.

> Canlı bir varlığın fiziksel ve zihinsel durumu: Мне посчастливилосъ/Ich hatte Glückşanslıydım. Örneklerde görüleceği üzere Rusçada öznesiz cümle yapıları canlıların fiziksel ve zihinsel durumlarını ifade etmek için kullanılsa da Almancada bu durum gerek sözdizimsel gerekse semantik yapı nedeniyle mümkün olamamaktadır.

$>$ Eylemin mümkün, arzu edilir ve gerekli olma durumu: Eмy не хочется zyлsmь/er will nicht spazieren gehen- gezmek istemiyor; Можно войти?/Darf ich eintreten?- girebilir miyim? Rusçada bu tür kullanımlar model fiillerle 'хотеть- хотеться: он не хочет- ему не хочется) ve farklı model anlamları içinde barındıran kalıplaşmış yapılarla; Almancada isteme, izin ve gereklilik durumları da yine örneklerden anlaşıldığı üzere tarz eylemlerle/Modalverben gerçekleştirilebilmektedir. 
$>$ Bir şeyin eksikliği, yokluk durumu: На небе ни облачка- gökyüzü açık/ bulut yok. Некого cnpocumb- soracak kimse yok. Almancada bu tür anlam es gibt/ vardır ya da es gibt kein(e)/ yoktur kalıplarıyla sağlanmaktadır. Sözdizimsel açıdan ele alındığında bu yapının da öznesiz cümle gibi kabul edilebileceği söylenebilir. Örn: Es gibt keine Wolken am Himmel/Havada bulut yok. Es gibt niemanden zu fragen/ Soracak kimse yok.

> Gerçek dışı, gerçek üstü (potansiyel) eylem: Вам не видать таких сражений!- Вӧyle savaşlar görmeyeceksiniz! Bам начuнать- siz başlayın(ız). Almancada ise, birinci örnekte görülen ifadenin karşıllı̆̆ Futur I ile yapılabilirken ikinci cümlede karşılaşılan emir durumu ise Imperativ ile karşılanabilmektedir. Almancada olduğu gibi Rusçada da bu yapıların gelecek zaman ve Imperativ ile oluşturulmuş varyasyonları da bulunmaktadir.

$>$ Eyleme iti (teşvik), komut, kategorik emir formları: He kypumb!/Rauch nicht!- Sigara içme!; Bceм cnamı!/ Schlaft ihr alle!- Herkes uyusun!

Yukarıda öznesiz cümlelerin semantik alanına giren kullanımlara yönelik verilen bazı örnekler Türkçeye aktarıldığında, herhangi bir 'öznesiz olma' durumunun var olmadığı algısı açığa çıkabilir. Bu noktada öncelikle Rusçadaki özne (подлежащее) ve eylemci (субъекm) terimlerini detaylandırmanın gerekliliği doğmaktadır. Rusçada özne (nод^ежащеe), eylemi gerçekleştiren (aktif) bir şahsa ya da nesneye direkt olarak işaret ederken, eylemci (cyбъekm) genellikle aktif (faal) olmayan, daha çok bir durumun, bir eylemin taşıyıcısı niteliğindeki şahsa veyahut dışarıdan etki alan bir nesneye işaret etmektedir. Stilistik (üslupbilim) ayrım gözetmeksizin gerek konuşma gerekse yazı dilinde; ana dil odaklı bakılırsa özellikle de Rusça- Türkçe dil çifti üzerine yapılan çeviri çalışmalarında bu durum hem öğretici hem de öğrenci açısından karmaşık bir hal alabilmektedir. Buradaki asıl mesele söz konusu dilleri dilbilimsel tipoloji noktasında iyi bilmenin yanında, dilin taşıyıcılarının, o toplumun bakış açısına, dünya görüşüne de hâkim olmaktır. Dolayısıyla, Rusçada bu tür ifadeler Türkçeye aktarılırken eylemi gerçekleştiren aktif bir özneden söz edilemese de eylemci ile nesne arasındaki ilişki değerlendirilmelidir. Almancada da kısmen benzer kullanımlar görülmesine karşın, dilbilgisel açıdan cümlede özne bulunması gerekliliği yukarıdaki örneklerden hareketle söylenebilir.

1.2.5 Инфинитивные предложения/ Infinitivsatz-Dasssatz (Mastar Cümleleri): Tek öğeli mastar cümlelerinde, eylemin gerçekleştiricisi/ taşıyıcısından bağımsız potansiyel bir eylem ifade edilmektedir. Mastar cümlelerinin bu anlamsal özelliği, temel öğenin doğasından kaynaklanmaktadır. Mastar cümle yapıları öznesiz cümle yapılarıyla benzerlik gösterdiği gibi, bu tür cümlelerde zorunluluk, teşvik (iti), gereklilik, olasılık ya da olasılıksızlık gibi farklı model (kiplik) anlamlar işaretlenebilir: Откуда ж знать тебе о нем, что он мой хучиий друз?/ Woher weißt du, dass er mein bester Freund ist?- Onun, benim en iyi arkadaşım olduğunu nereden biliyorsun? (Simonov, 2004, s. 53). Bunun yanında бbl parçacığılla kurulan mastar cümleleri kimi cümle yapılarında karşımıza 'arzu edilirlik' anlamında çıabilmektedir: Вам бы здесь до осени пожитьSonbahara kadar burada yaşasanız (Çehov, 1986). Bu kullanım Almancada Wunschsatz/Dilek cümlesi ile sağlanabilir. Bu durumda Almancadaki Konjunktiv II devreye girerek gerçek dışı anlam verilir. Sözdizimsel açıdan iki farklı kullanım mevcuttur. Birinci kullanımda Konjunktiv II durumundaki 
fiil cümle başına getirilerek anlam sağlanır: Würden Sie doch bis zum Herbst hier leben!/Sonbahara kadar burada yaşasanız! İkinci kullanımda ise yan cümle özelliği bulunan Wenn bağlacı cümle başına alınarak anlam sağlanmış olur: Wenn Sie doch bis zum Herbst hier leben! Ancak her iki kullanımın da Almancada yan cümle özelliği taşıdığı unutulmamalıdır. Almancada Konjunktiv ile sağlanan gerçek dışı anlamın Rusçada da olduğunu ve bu noktada geçmiş zamanlı fiil formunun ( $-\lambda$ ile biten) bir işaretleyici olarak «бbl» (б) ile kombinasyonunu unutmamak ayrıca önemlidir: Без тебя $\Omega$ не добрался бol до города...- sensiz (sen olmasaydın) şehre ulaşamazdım.

1.3 Rusçada ve Almancada Гдагодьное сказуемое/ Verbaler Satz Fiil Soylu ve Именное сказуемое/ Nominaler-Nonverbaler Satz İsim Soylu Yüklemler

Geçmişten günümüze ulaşan dilbilim yazıları ve gramer kitaplarında daha evrensel boyutta ele alınarak Номинативное предложение/Nominaler Satzl İsim cümlesi ve Предикативное предложение/Verbaler Satz/ Fïl Cümlesi terimleriyle karşımıza çıkan bu tür cümleler, bugün, işlevsellik noktasında da değerlendirilerek çoğunlukla yerel gramer kaynaklarında cümlenin temel öğelerinden biri olan yüklemin soyuna/ türüne göre isim/ fiil soylu yüklem olarak sınıflandırılmakta ve söz konusu sınıflandırma isim ve fiil cümlelerine karşılık gelmektedir.

\subsection{1 Глагольное сказуемое/Verbaler Satz (Fiil Soylu/ Fiil Yüklem)}

Kendi içinde basit ve bileşik fiil yüklemi olarak ayrılmakta ve Glazunova (2011, s. 146), basit fiil soylu yüklemin özellikleri, morfolojik göstergeleri, semantik alanı ve sözü edilen yüklemin ifade araçlarına yönelik geniş bilgi aktarmaktadır.

Basit Fiil Soylu Yüklem: Söz konusu eserde basit fiil soylu yüklemin başlıca ifade araçları arasında aşağıdakiler öne çıkmaktadır:

$>$ Fiilin kip, zaman ve şahıs formlarından herhangi biriyle: Я люблю тебя/ Ich liebe dich- seni seviyorum; Принеси мнне, пожалуйста, сумку-Bana çаntayı getir lütfen.

$>$ Eylemin enerjik başladığını ifade eden mastar formda bir fiille: Тебе надо было его сначала выслушать, а ты сразу ругаться- ӧпсе опи dinlemeliydin sen ise hemen küfrediyorsun. Burada 'a' (ise, fakat) bağlacının cümleye kattığı anlam dikkate alındığında, bu kullanımın Almancada da benzer şekilde bir bağlaç ile karşılandığ görülmektedir: Zuerst musstest $d u$ ihm/ihr zuhören, aber du schimpsft gleich ya da yine aynı anlamı verecek zwar ... aber bağlacı kullanılarak anlam aktarılabilir: Du musstest zwar ihm/ihr zuerst zuhören, aber du schimpfst gleich; koşul, imtiyaz, dilek veya yükümlülük anlamındaki emir kipiyle;

“Бог тебл накажет! - Tanrı cezanı versin!" şeklinde Rusçada yapılabilirken bu tür ifadeler Almancada Konjunktiv I' den yararlanılarak da sağlanabilir: Gott bestrafe dich! Temel ifade cümlesi dilbilgisi kuralına göre bestrafen fiilinin 3. Tekil şahsa göre çekimlenmesi gerekirken, bu kullanımda fiil Konjunktiv I formuna getirilerek dilek/koşul durumu sağlanabilmektedir.

Bileşik Fiil Soylu Yüklem: Bileşik fiil soylu yüklemin aşağıda sıralanan türde fiillerin mastar formlarıyla birlikte kullanıldığ görülmektedir (Glazunova, 2011, s. 146-147):

Bir eylemin başlangıcı, devamı veya sonu anlamına gelen yardımcı fiil: Мы начали работать- çalışmaya başladık; Я cmå ждать- beklemeye başladım; Он продолжал писать - 
yazmaya devam etti; Я бросил курить- sigarayı bıraktı. Almancada ise, bu tür anlamlar cümlede yine Infinitiv+zu yapısıyla verilebilmektedir: Wir begannen zu arbeiten; Ich begann zu warten; Almancada bazı fiiller eylemin devam ettiği anlamını kendi içinde barındırmaktadır: Er/Sie schrieb weiter-yazmaya devam etti; bununla birlikte bir alışkanlığın artık terk edildiğini belirtmek için Almancada bırakmak anlamına gelen aufhören fiili kullanılır. Fiil, ayrılabilen bir fiil olduğu için Sigarayı bıraktı cümlesi şu şekilde kurulabilir: Er/Sie hat aufgehört zu rauchen. Rusçada da yine bazı fiiller eylemin devam ettiği, bittiği ya da sonlandırıldığı anlamını içinde barındırmakta ve ayrıca fiiller, bitmiş/ tamamlanmış (сов.в.) ve bitmemiş/ tamamlanmamış (несов.в.) şeklinde türlere ayrılmaktadır. Bu noktada ise gerek semantik gerekse de morfolojik göstergeler ayrı ayrı önemlidir.

> Хотеть/захотеть,желать/пожелать,мочь/смочь,пьтаться/попытался, стараться/постараться,отказываться/отказаться, надеяться, бояться vе benzeri model fiiller: Я хочу видеть тебя- Seni görmek istiyorum. Bu anlam Almancada da model fiille sağlanabilmektedir: Ich möchte dich sehen. Они отказались нам помогать- bize yardım etmekten vazgeçtiler. Almancada ise, bu anlamı veren dass yan cümlesi veya ana cümle öznesi ile yan cümlede eylemi gerçekleştiren/gerçekleştirecek olan aynı özne ise Infinitiv+zu kurulur ve vazgeçmek anlamına gelen auf etwas verzichten yapısı ile anlam sağlanabilir: Sie haben daraufverzichtet, uns zu helfen/ dass sie uns helfen.

Kisa sifat formları ve должен, рад, намерен, способен, готов, склонен ve benzeri yapilar: Я рада тебя видеть- seni gördüğ̈̈me sevindim; Rusçadaki bu kullanım, dilin özelliği gereği kullanılırken Almancada böyle bir kullanım söz konusu değildir. Ancak Almancada da bu anlamı veren ana cümle- yan cümle kombinasyonu vardır ve bu kombinasyon yine dass bağlacı ile sağlanmaktadır: Es freut mich, dass ich dich gesehen habe. Я намерен продолжить это дело- bu işe devam etme niyetindeyim; Mы zотовы вам nомогать- size yardım etmeye hazırız. Bu tarz kullanımlar için ise, Almancada sözdizimsel açıdan bir eşdeğerlik bulunmamasına karşın semantik açıdan yine Infinitiv $+z u$ yapısıyla anlam sağlanabilmektedir: Wir sind fertig, Ihnen zu helfen-Size yardım etmeye hazırız; Ich beabscihtige, diese Arbeit fortzusetzen- $\mathrm{Bu}$ işe devam etme niyetindeyim.

\subsection{2 Именное сказуемое/Nominaler Satz (İsim Soylu/ İsim Yüklem)}

İsim Soylu/ İsim Yüklem: İsim soylu yüklemler aşağıda sıralanan farklı türlerdeki yapı ve dilbilgisel araçlarla farklı türlerde bağ/ ilişki kurabilir (Glazunova, 2011, s. 158):

Farklı formlarda быmь (olmak, bulunmak) fiili: Мне важно знать, кто он есть на самом de^e- Onun gerçektelaslında kim olduğunu bilmek benim için çok önemli; Moŭ omeu, бbı отличным врачом- Babam muhteşem bir doktordu. Almancada ise, isim cümlelerinde temel unsur sein/olmak yardımcı fiilidir ve cümle kurulurken özneye göre çekimlenmiş haliyle cümlede yerini alır. Şayet cümle, bir ifade cümlesiyse, Almancanın özelliği gereği çekimlenmiş sein fiili cümlede ikinci konumda; şayet soru cümlesiyse cümle başında yer almalıdır: Es ist für mich sehr wichtig, zu wissen, wer er eigentlich ist/ Onun aslinda kim olduğunu bilmek, benim için çok önemli ya da Mein Vater war ein wunderbarer Arzt/Babam muhteşem bir doktordu. Örneklerde de görüldüğü gibi, ikinci cümle basit bir isim cümlesi 
olsa da ilk cümlede ana cümle isim cümlesi olmasına karşın yan fiil cümleleriyle de bağlanabilmektedir. Ancak ana cümle bir isim cümlesi olduğundan, bu cümle için isim cümlesi demek yanlış olmayacaktır.

> Это, вот, значит (это значит) parçасıkları: Друг - это человек, на которого всегда можно положиться- Arkadaş, her daim güvenebileceğiniz kişidir. Almancada ise, Rusçadaki bu örnek Relativ yapılarıyla verilmektedir: Ein Freund ist jemand, dem Sie immer vertrauen können/ arkadaş, her zaman güvenebileceğiniz kişidir.

> Karşılaştırıcı bağlaçlar как, словно, будто, точно ve benzeri: Он как ребёнок- с̧осиk gibi; Её глаза будто острый нож- Gözleri keskin bir bıçak gibi. Almancada ise, bu kullanım gibi anlamına gelen wie edatıyla (Rusçada «kak») yapılabilir ama karşılaştırma sadece wie edatıyla yapılmayabilir. Kadar anlamına gelen als edatı da karşılaştırma bağlamında kullanılmaktadır: Weiss als Milch/Süt kadar beyaz; Unschuldig als Baby/Bebek kadar masum.

> Hareket, durum, aktivite fiilleri; hatta идти, стоять, лежать, сидеть, родиться, жить, умереть, работать, вернуться vе benzerleri: После отпуска они вернулись отдохнувшие- tatilden dinlenmiş şekilde döndüler; Он умер героем- Bir kahraman olarak öldü.

İsim soylu yüklem, farklı tür ve yapılardaki cümlelerde, farklı şekillerde karşımıza çıkabilmektedir. Cümle içerisinde bu yüklemler işletilirken, kimi zaman sadece isim türevi odaklı bakıldığından, teşhisi noktasında yanıltıcı durumlar da açığa çıkabilmektedir. Nitekim söz konusu yüklemler farklı dilbilgisel işaretlerle birleştiğinde, bakış açımızı yönlendirme, bu tür yapıları bir bütün olarak ele alabilme ihtiyacını da beraberinde getirecektir. Örneğin isim türevi yüklemlere, sifatlar (имена прилагательные), edatlı vеуа edatsı isim yapıları (имена существительные с предлогами или без предлогов), ortaçlar (причастия), zamirler (местоимения), zarflar (наречия) gibi dilin en belirgin öğeleri olarak rastlamaktayız.

\section{ESAS YARDIMCI FİIL БЫTb/SEIN ÜZERINNE}

Rus dilinde herhangi bir kişi ya da nesneyi belirli bir gruba ya da kategoriye dâhil etmede, sınıflandırmada бbımь fiilinin kullanımı, tıpkı Almancadaki sein fiilinin kullanılması gibi, kaçınılmazdır. Söz konusu fiilin çağdaş dildeki kullanımına yönelik öncelikli olarak değinilmesi gereken husus şimdiki zaman planında kullanılmasıdır. ${ }^{1}$

Bu özellik büyük ölçüde konuşma diline özgü olduğu gibi, yazı dilinde бbımь fiilinin yerini являтьься fiili almaktadır. Almancada ise, gündelik konuşma dilinde sein fiilinin çekimlenmiş hali ya Präsens/Şimdiki-Geniş Zaman (bin, bist, ist, sind, seid, sind) ya da Perfekt/Geçmiş Zaman ifadelerinde sıkça kullanılırken, yazı dilinde geçmiş zaman ifade edilirken sein fiilinin Präteritum hali olan war (war, warst, war, waren, wart, waren) kullanılmaktadır. Kıyaslayalım: Профессор Соколов- хороший вpay/ Professor Sokolov ist ein guter Arzt - Profesör Sokolov iyi bir doktordur. Профессор Соколов является лучшим специалистом по сердечно- сосудистыл заболеваниям/ Professor Sokolov ist ein sehr guter Experte auf dem Fachbereich der Herz-Kreislauf-Erkrankungen- Profesör Sokolov, kardiyovasküler hastalıklar alanında çok iyi bir uzmandır. Örneklerden görüldüğü üzere, Almancada

\footnotetext{
${ }^{1}$ Бblmb-ecmb- fiilinin şimdiki zaman 3. tekil şahıs formu özellikle yazı dilinde kullanılır.
} 
günlük konuşma veya yazı dilinde şimdiki/gelecek zamanlı isim cümlesinde sein fiilinde bir değişim söz konusu değildir. Ancak Futur I/ Gelecek Zamanda gelecekte olmak anlamina gelen werden yardımcı fiili tercih edilmektedir. Bu fiil tek başına kullanıldı̆̆ında olacak anlamına gelirken, Gelecek Zaman içerisinde kullanıldığında, yardımcı fiil görevinin olduğu unutulmamalıdır.

Çağdaş dilde бoımı fiilinin kullanımına yönelik aşağıdaki hususlar ayrıca önemlidir (Pehlivanova ve Lebedeva, 2007, s. 274-275):

$>$ Я Ялятьься fiili şimdiki zaman planında bir yardımcı fiil olarak kullanılmakta geçmiş ve gelecek zaman planında tercih edilmemektedir. Yukarıda verilen durumun tersi olarak söz konusu zamanlarda бbımь fiilinin zamana göre çekimli formları öne çıkmaktadır: Geçmiş

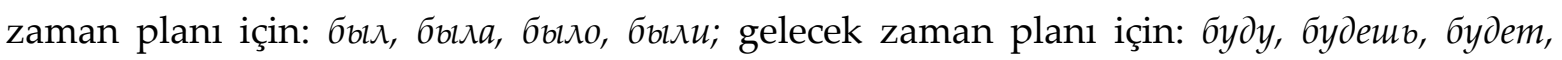
будем, будете, будуm.

$>$ Eğer kişi ya da nesnelerin sınıflandırılmasında belirli bir gruba ait olma durumu бbımь fiili ile ifade ediliyorsa ve özellikle de bu durum geçmiş ve gelecek zaman planında gerçekleşiyorsa, böylesi durumlarda isimler -ile (araç/ Instrumental) halinde kullanılmaktadır: Geçmiş zaman planı için: Я быıл студенmкой- Öğrenciydim (dişil); şimdiki zaman planı için: Я студентка (dişil)- Öğrenciyim. Gelecek zaman planı için: $Я$ бydy cmyденткой- Ö̆̆renci olacağım (dişil).

> Быmь fiili geçmiş ve gelecek zaman planında kurulmuş cümlelerde sıfatlarla (sıfatların kısa ve tam formları) veya sıfat-fiil (kısa formu) ile birlikte yüklemi oluşturabilir: Geçmiş zaman: Фильм был интересный- film ilgi çekiciydil Дочь была похожа на отц̧а/kız babaya benziyordu; şimdiki zaman: Фильм интересный- Film ilgi çekicil Дочь похожа на отиза- Кız babaya benziyor; gelecek zaman: Фильм бydem интересный-Film ilgi çekici olacakl Дочь бydem похожа на отиза-Kız babaya benzeyecek².

$>$ Быıь işaretleyebilir: Geçmiş zaman: Она была в университете (вчера)- O üniversitedeydi (dün); şimdiki zaman: Она в университете (сегодн)- О ӥniversitede (bugün); gelecek zaman: Она будет в университете (завтра)- О ӥniversitede olacak (yarm).

$>$ Kişi ya da nesnelerin yokluğu ifade ediliyorsa, bu noktada cümle şahıssız olarak tercih edilmektedir: У нас нет (не было, не будет) машинь- Arabamız yok (olmadl, olmayacak); Taм нет (не было, не будет) университета -orada üniversite yok (yoktu, olmayacak).

$>$ Быть fiili geçmiş zamanda ходил, ездил куда- либо anlamlarında kullanılabilir:

Где вы были вчера вечером? - Dün akşam neredeydiniz?

- Mь были на концерте-Konserdeydik.

- Mьх ходили на концерт. - Konsere gittik ('yürüyerek' gidip geldik).

\footnotetext{
${ }^{2}$ Bu konuda detaylı bilgi için Bkz: Pehlivanova, Lebedeva, s. 274.
} 
3. RUSÇADA VE ALMANCADA УTВEPДИТЕЛЬНЫЕ ПРЕДЛОЖЕНИЯ/AFFIRMATIVER SATZ/ OLUMLU VE OTРИЦАТЕЯЬНЫЕ ПРЕДЯОЖЕНИЯ /NEGATIVER SATZ/ OLUMSUZ CÜMLELER

Semantik açıdan değerlendirildiğinde, Rusçada cümlenin en önemli olaylarından biri onay/ kabul ve inkâr/red; yani olumlu ve olumsuz dualitesidir. Bu tutum, konuşmanın içeriği ile öğeleri arasındaki bağlantının onaylanması veya reddedilmesiyle kendini gösterir. Bu noktada kipsellik (modellik) önemlidir çünkü eylemi ya da yargıyı inkâr etmek veya tam tersi onaylamak gerçeklik planıyla yakından ilişkilidir. Dil dizgesinde bu karşıtlı̆̆ın belirgin göstergeleri, ifade araçları vardır. Böylece cümle anlamca olumlu ya da olumsuz bir nitelik kazanmaktadır. Olumlu cümlelerin başlıca dilbilgisel göstergesi olumsuz sözcük Hem ('hayır', 'yok'), olumsuzluk parçacığ 1 не (değil), ни (tek, bir, hiç) ve de нельзя (olmaz), невозможно (mümkün değil) gibi yapıların yokluğudur: Победа будет за нами-zafer bizim olacak.

Terim olarak 'olumsuz' multidisipliner niteliktedir. Sözdizimsel çerçevede ise 'отрицุаниe' yani 'olumsuz' terimi, не ve $н$ u parçacıklarının, söz konusu $\mathfrak{H e}^{-}$ve $\boldsymbol{H} \boldsymbol{u}$ - öneke sahip zamir ve zarfların; ayrıca нельзя ve sözcüksüz bir dizi yüklemin kullanımına yönelik durumları bünyesinde barındırmaktadır. 'Olumlu' ve 'olumsuz' terimleri birbiriyle yakından ilişkilidir. Herhangi bir durumu değillemek, dolaylı olarak onun tersini onaylamak anlamına gelmektedir. Kısaca, bir şahsın, nesnenin ya da eylemin varlığını inkâr etmek, aynı zamanda onun yokluğunu bildirmektir.

Almancada olumsuz cümle, cümlenin olumsuz yapılması ve sözcüğ̈̈n olumsuz yapılması şeklinde iki türlü yapılabilir. Cümlenin ya da sözcüğün anlamını olumsuz yapan sözcükler şu şekildedir: nicht, nie, nichts, niemals, keiner, kein, keine, keines, keinesfalls, keineswegs, niemand vs (Zengin, 2012, s. 119).

Bir cümle içerisinde olumsuzluğu ifade etmenin yolları ve söz konusu ifadenin dilbilgisel araçları aşağıdaki gibi sıralanabilir:

$>$ Herhangi bir kelime formunun önünde yer alabilecek не parçacığı: Она не работает- (о) çalışmıyor. Almancada bu anlam, cümle olumsuz yapılarak ya da eylem değillenerek verilmektedir: Er arbeitet nicht. Сестра не студенткаl Meine Schwester ist keine Studentin/Schülerin- (kız) kardeşim öğrenci değil; hatta deyim ifadelerinde: He в cuлax/Es ist nicht möglich/unmöglich-olanaksız/ mümkün değil. Örnekten görüleceği üzere, Almancada bir zarf değilleneceği zaman, olumsuzluk sözcügü olan nicht zarftan önce kullanılarak olumsuz anlam sağlanmaktadır. Ancak bir isim olumsuz yapılacağı zaman, sözcükten önce getirilecek kein olumsuzluk sözcüğü ile bu anlam sağlanmaktadır.

> Ни parçасığı: Ни одного вопроса- Tek bir soru (bilel olsun); Ни малейшего волнения (еп иfak bir heyecan bile/ olsun) tipi cümlelerde ve hatta deyim ifadelerinde karşımıza çıkabilmektedir.

$>$ Некого, нечего, негде, некуда, неоткуда, незачем, некогда gibi не- ӧn ekli olumsuz zamir ve zarflar: Hе о чем neчалumьcs- Üzülecek bir şey yok; Hezde omdoxнymb- Dinlenecek yer yok. Huönekli zamirler ve zamir türevi никто, ничто, никакой tipi sözcükler: Ничего нового- Yепі bir şey yok. Almancada bu anlam yine nicht ve kein sözcükleri ile sağlanmaktadır.

$>$ Yüklem konumundaki нет, нельзя, невозможно, немыслимо: Нет времени- zатап yok; Exать нельзя- Gidemezsin/gidilmez ve olumsuz cümlenin eşdeğeri olarak Hem sözcüğü 
veyahut yanıt veya karşıtlıkta kullanılan esas öğesi: Oна на paбome? - Hem- (o) işte mi? -

Hayır; Все пришли, а она нет- Herkes geldi ama o gelmedil yok; На улице холодно а дома нет Dışarısı soğuk ama ev değil.

Yukarıda sıralanan dilbilgisel araçlar, kuşkusuz, Rusça ve Almancada basit cümlenin olumsuz ifadesi noktasında önemli rol oynamaktadır. Cümledeki olumsuzluğun türü ve derecesi noktasında ise olumsuz cümleler yine kendi içerisinde ayrılmaktadır. Bu noktadan hareketle, kimi cümlelerde olumsuzluk anlamı zorunlu bir unsur olarak ortaya çıkabilir. Örneğin bir şeyin veya bir kimsenin yokluğu, herhangi bir yerde bulunmayışı, bir eylemin gerçeklik planında yer etmediği, gerçekleşmediği gibi durumlar cümlede olumsuzluğun kaçınılmaz olduğu durumlardır: Нет времени/Keine Zeit!- zaman yok; Никаких проблем/ Kein Problem!- Sorun yok/ değil.

\subsection{Rusçada Cümlenin Zorunlu İşareti Olarak Olumsuzluk}

Olumsuzluk anlamının zorunlu olduğu cümlelerde yapısal, dilbilgisel ve olumsuzluğun niteliği noktasında farklılıklar açı̆̆a çıkabilir.

He (değil) parçacığı, Hu parçacığı ve ayrıca He- önekli zamir ve zarflar cümlelerde zorunlu bir işaret olarak yansımaktadır: Письмо не получено- Mektup alınmadl; Некуда nойти- gidecek yer yok; Не былю ни одного человека- tek bir kişi bile yoktu. Bunun yanında zorunlu olumsuzluk barındıran cümlelerin özneyi belirsiz veya genel bir özne olarak işaretlemesi daha olasıdır: Без потерь войны не бывает- Kayıpsız savaş olmaz (Simonov, 2013). İsteğe bağlı olumsuzluk içeren cümlelerin ise, bilinen belirli bir özneyi işaretleme olasılığı daha yüksektir ve dolayısıyla bu cümleler öznenin varlığını inkâr etmez: Не было сказано ни слова- tek kelime konuşulmadı/ edilmedi.

\subsection{Cümleye Eşdeğer "Hem" ve "Nein" İfadesi}

Cümleye eşdeğer ya da onun başlıca ögelerinden olan Hem, ikili veya çoklu diyaloglar içerisinde veya muhalif/ karşıt yapıların parçası olarak işletilmektedir. Diyalog metinler içerisinde verilen bilgi veya ifadenin yanıtı olarak karşımıza çıkabilen $\mathrm{Hem}$, böylesi durumlarda bir soru özelliğine ve de olumsuzluk anlamına sahip olabilir. Kimi zaman ise söz konusu unsurları barındırmayabilir. Eğer ifade edilene verilen yanıt belirgin, somut bir olumsuzluk barındirmiyorsa, yanıt içerisinde yerleşen Hem olumsuzluk unsuru olur: Имеете ли вы с кем из своих переписку? - Hem- Herhangi birinizle herhangi bir yazısmanız var mı? Hayır (Şolohov, 2003, s. 174). Ancak Almancada sadece sorulan bir soruya olumsuz yanit verilirken kullanılmaktadır: Ist er gekommen? -Nein/(o) geldi mi?- Hayır. Bu kullanım dışında, Almancada sorulara olumsuz cevap vermek için kullanılan tek sözcüklü cevaplar da bulunmaktadır: keineswegs, nie vs.

Kimi durumlarda da eğer ilk replik olumsuzluk içeriyorsa Hem olası iki yanıta karşılık gelebilir: İlkinde olumsuz bir yanıtı onaylayan нет: Tьл не написал nисьмо? - Mektubu yazmadın mı? - Hem, не написал- Hayır, yazmadım; ikincisinde ise olumsuz bir yanitı reddetmeye, bir duruma itiraza veya bu noktada bir anlaşmazlığa hizmet edebilir: To не написал nuсьмо? Mektubu yazmadın mı? - Hem, нanucas.- Hayır, yazdım. Almancada ise, buna karşılık gelen doch sözcüğü bulunmaktadır. Doch sözcüğü olumsuz bir soruya olumlu cevap vermek için kullanılır: Hast du den Brief nicht geschrieben?- Doch!- Mektubu yazmadın mı? - Bilakis/aksine/yazdım. Bu soru, konuşulan kişinin hiç mektup yazıp yazmadığını öğrenmek için yöneltilebilir. Bu durumda cümle kurulumu 
şöyle olacaktır: Hast du keinen Brief geschrieben?- Doch!- Hiç mektup yazmadın mı?- Aksinelyazdım. Almancada olumsuz sorulara cevap verilirken unutulmaması gereken temel kural, eğer cevap olumlu olacaksa doch sözcüğü mutlaka kullanılmalıdır. Şayet olumsuz soruya olumsuz yanıt verilecekse, o zaman Nein sözcüğünü kullanmak yeterli olacaktır: Hast $d u$ den Brief nicht geschrieben?- Nein.- Mektubu yazmadın mı? Hayır/yazmadım.

Rusçada, iki öğeli cümlelerde, temel öğelerden herhangi biri ile olumsuzluk ifade etmek mümkündür. Bunun yanında, genellikle yüklemden önce; özne olmayan yüklemlerde ise fiilden veya yüklemden önce yerleşebilir. Tam olumsuz cümlelerin aksine, bu tür yapılarda sadece yüklemde olumsuzluk açı̆̆a çıkar: Он не знает- (O) bilmiyor; Ezo сестра не журналист- Kız kardeşi gazeteci değil; Новости не из Aнкары- Haberler Ankara'dan değil; Времени не хватает- Zaman yetmiyor (yeterli değil). İsteğe bağlı olumsuzluk cümlenin isim soylu bir öğesi olarak kendini gösterebilir. İsim cümlelerinde kimi zaman emir/ direktif; Не разговаривать!- Копиşта! İsim cümlelerinde yerleşen olumsuz anlamlar için belirgin işaretleyiciler olabileceği gibi, bazı durumlarda bu tür olumsuzluğun niteliği bağlama (kontekst) dayalı da olabilmektedir.

Смотрела она на нас смело, вупор, словно мы были не новые для нее люди, а животные зоологи ческого сада -Bize cesurca ve de boş baktı; sanki onun için yeni insanlar değgil de hayvanat bahçesindeki hayvanlarmışız gibi (Çehov, 2010, s. 265) tipi cümlelerde bir öğede yerleşen olumsuzluk tümüyle bir grubu etkileyebilir; bu noktada yine bağlam son derece önemlidir.

3.3 Общеее и частное отрицание/Vollnegation-Teilnegation/ Tam ve Kısmi Olumsuzluk

Cümlede olumsuzluğun tam ve kısmi boyutlarını aşağıda verilen cümleler üzerinden değerlendirmeye çalışalım:

> Брат 수 ходил вчера в библиотеку./Erkek kardeşim dün kütüphaneye gitmedi (yürüyerek gidip gelmedi)

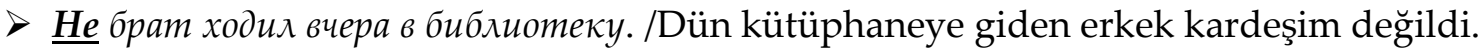

> Брат ходил не вчера в библиотеку. /Erkek kardeşim kütüphaneye dün gitmedi.

> Брат ходил вчера 쓰 в библиотеку (Online IV)./Erkek kardeşim dün kütüphaneye gitmedi. (bir yere gitti ama kütüphaneye değil).

Almancada da bu tür anlamlar, Rusçadaki нe gibi, cümle içinde nicht olumsuz sözcügünün hangi sözcük önüne getirildiğine bağlı olarak değişkenlik göstermektedir:

> Mein Bruder/Meine Schwester ist gestern in die Bibliothek nicht gegangen./ Erkek/kız kardeşim dün kütüphaneye (yürüyerek) gitmedi.

Wer gestern in die Bibliothek gegangen ist, war nicht mein Bruder/meine Schwester./ Es war nicht mein Bruder/meine Schwester, der/die gestern in die Bibliothek gegangen ist./ Dün kütüphaneye giden erkek/kız kardeşim değildi.

Mein Bruder/Meine Schwester ist nicht gestern in die Bibliothek gegangen./ Erkek/kız kardeşim kütüphaneye dün gitmedi.

Mein Bruder/Meine Schwester ist gestern nicht in die Bibliothek gegangen./ Erkek/kız kardeşim dün kütüphaneye gitmedi. (bir yere gitti ama kütüphaneye değil)

Bu cümleler anlaşılacağı üzere olumsuzluk ifadesinin farklı niteliklerine işaret etmektedir. İlk örneğimizde yapılan eylem olumsuzlanmaktadır. Bu noktada cümlenin bütününe yansıyan bir 
olumsuzluk söz konusudur. Cümlenin temel öğelerinden birinde (yüklem) yerleşen olumsuzluk anlamı böylece bütün bir ifadeyi kuşatmış olur. Böylesi olumsuzluk ifadeleri tam; bu tür olumsuzluk içeren cümlelere de 'tam olumsuz' cümleler adı verilmektedir. İkinci örneğimizde açı̆̆a çıkan olumsuzluk anlamı, eylemin taşıyıcısına yöneliktir. Bu noktada cümleyi büsbütün olumsuzlaştıran bir durumdan bahsedilemez; kısaca eylem olumsuzluk ifade etmez. Kütüphaneye giden biri vardır fakat bu erkek kardeş değil; başka biridir. Üçüncü örneğimizde reddedilen ya da olumsuzluk bildirilen husus eylemin kendisi değil; zamanıdır. Dolayısıyla açığa çıan anlam şöyledir: Erkek kardeş kütüphaneye gitmiştir ancak bu kütüphaneye gitme eylemi dün gerçekleşmemiştir; dolayısıyla bir başka zaman aralığında gerçekleşen bu eylem için olumsuzluk söz konusu değildir. Son örneğimizde ise, eylemin yeri noktasında bir olumsuzluk söz konusudur. Yine olumsuzluk anlamı cümlenin tümüne değil, bir kısmına atıfta bulunur. Erkek kardeş dün kütüphaneye gitmemiştir ancak herhangi başka bir yere gitmiştir. Bu tür olumsuzluklar kısmi olumsuzluk, böylesi olumsuzluk içeren cümleler de 'kısmi olumsuz' cümleler olarak adlandırılmaktadır.

Tam/ kısmi dualitesinde genel geçer normların dışında kalan ve de özellikle üzerinde durulması gereken durumlar da vardır. Nitekim yukarıda, cümlenin temel öğelerinden birinde yerleşen olumsuzluğun (yüklem) cümlenin tümüne sirayet ettiği üzerinde durulmuştu. Oysa kimi zaman yüklemdeki bu olumsuzluk kısmi bir karakter de kazanabilir: Не ходилв библиотеку, а ездил/Mein Bruder/Meine Schwester ist gestern in die Bibliothek nicht gegangen, sondern gefahren (kütüphaneye yürüyerek değil, arabayla gitti). Örnekte de görüldügü gibi eylemin tümü reddedilmemekte, yalnızca eylemin niteliği, eylemi gerçekleştirme şekli konusunda bir olumsuzluk açığa çıkmaktadır. Bunun yanında, çalışma içerisinde morfolojik göstergeleri ve semantik alanı üzerinde özellikle durduğumuz, olumsuzluğun zorunlu olduğu cümlelerin tümü tam olumsuz cümlelerdir. Tam ve kısmi olumsuzluğun haritası belirgin hatlarla da çizilmiş olabilir. Örneğin He parçacığının yüklem ya da temel öğenin önünde yerleşmesinin tam olumsuz; cümlenin öznesinde ya da cümlenin ortak öğesinde yerleşmesinin ise kısmi olumsuzluk oluşturması gibi. Bununla birlikte, söz konusu sınırın çizilmesinde farklı parametreler de açığa çıkabilir (Online V):

$>$ Fiilin çekimli formu ve ona bağlı sözcük biçimleri içeren cümlelerde olumsuzluk, şayet He parçacığı doğrudan çekimli fiil formunun önüne gelirse tam olumsuz nitelik kazanmaktadır; ancak eğer fiile bağımlı bir sözcük biçiminden önce gelirse kısmi olumsuz özelliğe sahiptir: Она 쓰 может работать/ Она может не работать Bu kullanım Almanca için söz konusu olmamakla birlikte sözcük önüne getirilen nicht ve kein olumsuzluk sözcükleri cümleyi ya da bir sözcüğü olumsuz yapabilir. Bunun dışında bazı zarfların önüne getirilen olumsuzluk ön ekleriyle zarf ve/veya dolayısıyla cümle de olumsuzlaştırılabilir: Es ist unmöglich/ nicht möglich- Mümkün/ olası değil. Bu tip kullanım ve varyasyonlar Rusçada da yaygındır: Это невозможно- bи mümkün değil.

Fiilin çekimli formunu içermeyen cümlelerde, olumsuzluğun tam veya kısmi niteliği ancak, sözdizimsel zaman ve kipin özel bir göstergesinin olduğu özgül olmayan biçimlerle belirlenebilir. Şöyle ki, Mamь не вpaч-Meine Mutter ist keine Ärztin-Annem doktor 
değil; Он не домаl Sie ist nicht zu Hause- O evde değil gibi cümleler hem tam hem de kısmi olumsuz olarak algılanabilir: Мать не врач-'не является врачом'- doktor değil' veyahut 'является не врачом, а журналистом/ Meine Mutter ist keine Ärztin aber eine Journalistin- Doktor değil ama gazeteci'; Он недома-'не находится дома-Evde değil' veyahut 'находится не дома- Evde değil fakat başka yerde'/ Sie ist nicht zu Hause, aber in einem anderen Ort.

> Yardımcı fiilden önce yerleşen olumsuz ifade, tam olumsuz bir karaktere sahiptir: Наружность её не была обманчива- Gӧrӥпӥşӥ̈ aldatıcı değildi; Ааврецикий не был молодым человеком-Lavretski genç bir adam değildi (Turgenyev, 1981, s. 31). Almanca SVO (ÖYN) özellikli dillerden olduğu için temel ifade cümlelerinde özne ilk sırada ve yüklem mutlaka ikinci sırada olmalıdır. Bu sebeple Almancada temel ifade cümlelerinde özne ile yüklem arasına bir sözcük getirilmesi söz konusu değildir.

$>$ İsimlerden önce yerleşen olumsuzluk ifadesi kısmi niteliktedir: Платье на нем было не ново и узко, словно он из него вырос- Üzerindeki elbise nе yеni nе de dardl; sanki içinden çıkmış gibiydi (Turgenyev, 2014). Bu örnekteki cümle Almanca karşılığ1 konusunda istisna oluşturmaktadır. Almancada iki olumsuzluk aynı anda verilirken weder .... noch/ ne ... ne de yapisı kullanılmaktadır: Ihr/Sein Kleid war weder neu noch eng; als ob er/sie herausgekommen wärel elbise ne yeni ne de dardr; sanki içinden çıkmış gibiydi; Он был не трус, как видно/ Er war nicht so feige, wie er aussah- Göründüğ̈̈ gibi, korkak değildi.

\section{4 Двойное отрицание/ Çift Olumsuzluk}

Olumsuz cümlenin doğasına, çeşitliliğine ve bu çeşitliliğin niteliklerine değinirken özellikle altının çizilmesi gereken bir diğer husus da bir cümlede birden fazla olumsuzluk ifadesinin, çift olumsuzluğun yerleşebileceği gerçeğidir. Örneğin yüklemin bileşiminde veya tam olumsuz bir cümlenin her iki temel öğesinde de olumsuzluk bulunabilir. Bu durumun bir sonucu olarak olumsuz anlam geri planda kalır ve farklı model anlamların kategorik ifadeleri açığa çıkabilir: mecburiyet, zorunluluk, gereklilik, kaçınılmazlık ve benzeri.

Нельзя, невозможно tip yükleme sahip olan ve fiilin mastar formu önüne yerleşen нельзя не сказать - (надо, необхоимо сказать- söylemek gerekli/ söylenmeli), Невозможно не сделать (надо обязательно сделать- yapmak gerekli/ yapılmalı) şeklinde olumsuzluk ifadesine sahip Я думаю, что нельзя будет не ехать (L. Tolstoy, 2008, s. 85) Bencel sanırım gitmemek imkânsız olacak tipi ve olumsuzluk durumunun ммочь (-e bilmek, -a bilmek) fiilinin çekimli formu veyahut bu fiile bağlı mastarın önünde yerleştiği cümlelerde çift olumsuzluk durumu açığa çıkmaktadır. Yine kimi zaman da «не имеет права», «не имеет основания», «не в силах» (не может-оlamaz) kombinasyonlarında ve Никтонеимеетправанезнатьжизни- Kimsenin hayat bilmeme hakk yoktur (Gonçarov, 1869) tip cümlelerde de çift olumsuzluk söz konusudur. Almancada basit cümlelerde bu tür olumsuz ifadeler fiilin ya da zarfın kendinden olumsuz anlamıla birlikte cümlede yer alması ve bu olumsuz anlamın değillenmesi için kullanılacak nicht sözcügü ile gerçekleştirilebilir. Ancak birden fazla cümlenin olumsuzlanacağı durumlarda Almancada Infinitiv $+z u$ ya da dass ile yan cümlenin kurulması gerekliliği unutulmamalıdır: Es ist nicht 
unmöglich/İmkânsız değil. Ya da Es ist nicht unmöglich, dass die türkische Fußballmannschaft die deutsche Fußballmannschaft schlägt/ Türk futbol takımının Alman futbol takımın yenmesi imkânsız değil.

\section{SONUÇ}

Dilin çok fazla tanımı olsa da dili bir bütün olarak incelemek yerine konuşulan dillerden bir ya da birkaçı ile incelendiğinde, daha tutarlı sonuçlara ulaşılmaktadır. Dünya üzerinde konuşulan Rusça ve Almanca, çalışmada ele alınmıştır. İki dilin birbirinden tamamen farklı alfabesi, gramer yapısı ve dil kolu olsa da, Rusça ve Almanca temel ifade cümlelerinin benzerlik ve farklılıkları ayrıntılı bir biçimde ortaya konmaya çalışılmıştır. Cümle türlerinden basit cümle incelendiğinde, Rusçanın sözdizim açısından biraz daha esnek bir dil olduğu yargısına ulaşılmıştır. Almancada Rusçadaki gibi tek ögeli cümle olmadığ özne ve yüklem olması şartıyla Almancada da bu tür kullanımın olduğu görülmüştür.

Rusçada belgisiz özneli kullanımda, şahıs zamiri öngörülebilir nitelikte olsa da cümlede bir özne olma zorunluluğu yokken, Almancada es adılının bulunma zorunluluğu tespit edilmiştir. Yine temel ifade cümlelerinde, Rusçada ismin hallerine göre ismin kök ve gövdesinde değişiklikler olurken ve de belirgin bir işaret olarak Окончание/Flektion (çekim eki) açığa çıkarken, Almancada ise, sadece isimden önceki tanımlıklarda (Artikel) değişiklik görülmüştür. Almancada istisnai bir durum olmakla birlikte, bazı zayıf çekime uğrayan isimlerde isme son eklerin (Suffix) eklendiği tespit edilmiştir. Rusçada sözdizime bağlı olarak basit cümle olarak kabul edilen bazı cümlelerin sözdizimsel ve semantik açıdan eşdeğerliklerinin Almancada bileşik cümlelerle sağlandığı saptanmıştır.

Rusça ve Almanca emir cümleleri incelendiğinde, Rusça ve Almancada 2. Tekil ve Çoğul Şahıs emir kipinde özne gerekliliğinin bulunmadığı ama emre konu olan fiilin çekimiyle hitap edilen kişinin kim olduğu sorusuna cevabın bulunduğu görülmüştür. Örneğin Rusçada 2. tekil ve çoğul şahıs için: Сıymaŭ!/ Dinle; Сıymaŭ(me)!/ Dinleyiniz. Bu kullanımın ayrıca bir nezaket ifadesi de olabileceğini dikkate almak gerekmektedir. Bunun yanında kimi zaman özellikle de konuşma dilinde bu yapıların stilistik bir engele takılmaksızın tercih edildiğini de söylemek yerinde olacaktır.

Rusça mastar cümlelerinin tek tip kullanımının olduğu, ancak Almancada sözdizimsel ve semantik açıdan bu kullanımların eşdeğerliklerinin bir Infinitivsatz ya da Dasssatz ile karşılandığ görülmüştür. Bir dilek anlamı barındıran Rusça yapıların eşdeğerliklerinin ise, Almancada yan cümle özelliği bulunan wenn bağlacı ve doch sözcüklerinin kullanımıyla ya da wenn bağlacının kaldırılarak cümlenin fiilinin başa getirilmesiyle karşılandığı saptanmıştır. Rusça ve Almancada olumsuz cümlelerin birbirine kısmen benzer kuruldukları görülse de Rusça olumsuz cümlelerdeki özne ve yüklem arasına giren olumsuzluk sözcügünün Almancanın gramer yapısı gereği özneyüklem arasında konumlandırılamadığı tespit edilmiştir. Ayrıca Almancada da Rusçada olduğu gibi, birden fazla olumsuzluk sözcüğü olduğu görülmüş ve bu sözcüklerin fiil cümleleri olumsuz yapılırken değişime uğramadığı̆, ancak isim cümleleri olumsuz yapılırken kein sözcüğünün ismin uygun tanımlığına göre “-e, -er, -en, -em, -es” son eklerini aldığı tespit edilmiştir. Rusçada olumsuz soruya Hem cevabı verilirken Almancada olumsuz soruya olumlu cevap vermek için doch, 
olumsuza olumsuz cevap vermek için ise nein sözcügünün kullanıldığı görülmüştür. Yine olumsuz cümlelerde hem Rusçada hem de Almancada olumsuzluk sözcüğünün yer değiştirebildiği ve kendinden sonra gelen sözcüğü değillediği saptanmıştır.

Almancada bazı sıfatlara/zarflara getirilen olumsuzluk ön eklerinin sıfatları/zarfları olumsuz yaptığı, böyle durumlarda anlamın olumlu olabilmesi için sıfattan/zarftan önce nicht sözcügünün getirilerek iki olumsuzdan bir olumlu anlamın sağlandığı dikkati çekmiştir. Rusçada da bu kullanıma karşılık birden fazla olumsuzluk barındıran, çalışma içerisinde çift olumsuzluk başlığı altında incelenen yapıların kullanıldı̆̆ı tespit edilmiştir.

Sonuç olarak birbirinden farklı yapıları, alfabeleri ve özellikleri bulunmasına karşın, Rusça ve Almancanın temel ifade cümlelerinde yer yer benzer özellikler gösterdiğini söylemek yanlış olmayacaktır. Her iki dili karşılaştırmalı öğrenmek isteyen dil öğrenicisinin çalışmada bahsi geçen temel cümle öge diziliş farklarını dikkate aldığında, öğrenmek istediği bu dilleri ya da bu dillerden birini sorun yaşamadan öğrenebileceği düşünülmektedir.

\section{KAYNAKÇA}

Bak, Hadi (2020). Türk Öğrencisi Bakış Açısıyla Ruscada Cümle ve Basit Cümlelere Dair Bir Değerlendirme. Atatürk Üniversitesi Sosyal Bilimler Enstitüsü Dergisi. 24 (4): 1833-1839.

Bloomfield, Leonard (1933). Language. New York: Holt, Rinehart and Winston.

Chomsky, Noam, (1965). Aspects of the Theory of Syntax. Cambridge: M. I. T. Press.

Çehov, Anton Pavloviç, (1889). Tragik ponevole,(web: https://ilibrary.ru/text/966/p.1/index.html, Erişim Tarihi: 20.05.2021).

Çehov, Anton Pavloviç, (1977). Nevesta, Rasskazı i povesti 1898- 1903, M: Nauka, s. 202-220.

Çehov, Anton Pavloviç (2010). Vişnevıy sad, Harkov 'Folio'.

Darancık, Yasemin ve Balcı Umut (2017). Dilbilimsel Açıdan Tümce Analizi: tümce Tanımlamalarına Karşılaştırmalı Bir Yaklaşım, ICOPEC Proceeding Book. Belgrade.

Eker, Süer (2009). Çă̆daş Türk Dili. (5. baskı). Ankara: Grafiker Yayınları.

Glazunova, Olga İgorevna (2011). Grammatika russkogo yazıka v uprajneniyah $i v$ kommentariyah, Sintaksis, Zlatous, St.Peterburg: ZAO Zlatoust.

Gonçarov, İvan Aleksandroviç (1869). Obrıv. (web: http://www.worldart.ru/lyric/lyric.php?id=2222\&public_page=4, Erişim Tarihi: 01.09.2021).

Gross, Harro (1998). Einführung in die Germanistische Linguistik. München: Iudicium Verlag GmbH. Helbig, Gerhard ve Buscha, Joachim (2000). Übungsgrammatik Deutsch. Berlin: Langenscheidt KG.

İkiz, Büşra (2019). Ana Dıli Söz Diżmi Tipolojisinin Yabancı Dıl Olarak Türkçe Ögřretimine Etkisiı: Yüksek Lisans Tezi, Ankara.

İmer, Kamile, Kocaman, Ahmet ve Özsoy, A. Sumru (2011). Dilbilim Sözlü̆̆̈̈. (1. basım) İstanbul: Boğaziçi Üniversitesi Yayınevi.

Kalyuta, Aleksandr (2010). Pratik Rus Sentaksı. İstanbul: Multilingual Yayınları. 
Kozan, Olena (2019). Rusya'da dilbilimsel çeviri kuramı: Temel yaklaşımlar ve kavramlar, RumeliDE Dil ve Edebiyat Araştırmaları Dergisi, (15), 313-327. DOI: 10.29000/rumelide.580620.

Lekant, Pavel Aleksandroviç (2004). Sintaksis prostogo predlojeniya v sovremennom russkom yazıke, Uçebnoye posobiye, Moskva: Vısşaya şkola.

Meçkovskaya, Nina Barisovna (2003). Strukturnaya i sotsialnaya tipologiya yazıkov. Flinta-Nauka. Moskva: İzdatelstvo «Flinta».

Pehlivanova, Kira İordanovna ve Lebedeva, Marina Nikolayevna (2007). Grammatika russkogo yazıka v illyustratsiyah, Russki yazık, Moskva.

Reformatski, Aleksandr Aleksandraviç (1997). Vvedeniye v yazıkoznaniye. Aspekt-Press.

Shakhin, Zulfiya (2009). Dillerin Tipolojik Sınıflandırması, Yüksek Lisans Tezi, Ankara.

Simonov, Konstantin Mihayloviç (2004). Stihotvereniya i poemı povesti raznıh let poslednyaya rabota (web: https://books.google.com.tr/books, Erişim Tarihi: 20.05.2021).

Simonov, Konstantin Mihayloviç (2013). Soldatami ne rojdayutsya (web: https://books.google.com.tr/books, Erişim Tarihi: 20.05.2021).

Şolohov, Mihayl Aleksandraviç (2003). Tihi don. Olma- Press Zvyezdiy mir.

Toklu, Mehmet Osman (2011). Dilbilime Giriş. Ankara: Akçă̆ Yayınevi.

Tolstoy, Lev Nikolayeviç (2008). Anna Karanina. St. Peterburg: Azbuka.

Turgenyev, İvan Sergeyeviç (1981). Dvoryanskoye gnezdo. Glava XXXI, Nauka.

Turgenyev, İvan Sergeyeviç (2014). Rudin. (web: https://www.livelib.ru/book/20909/read-rudinivan-turgenev/ 4, Erişim Tarihi: 03.09.2021).

Velupillai, Viveka (2012). An Introduction to Linguistic Typology, Amsterdam. Philadelphia: John Benjamins Publishing Company.

Zengin, Dursun (2007). Her Yönüyle Modern Almanca, Deutsche Grammatik. 2. Baskı. Ankara: Kurmay Yayınları.

Zengin, Dursun (2012). Deutsche Grammatik, Her Yönüyle Modern Almanca. 8. Baskı. Ankara: Kurmay Yayınları.

\section{Elektronik Kaynaklar}

Online I: https://sozluk.gov.tr/, Erişim Tarihi: 01.05.2021.

Online II: https://wals.info/languoid, Erişim Tarihi: 02.05.2021.

Online III: https://mogu-isat.ru/spravochnik/?wiki_name=Бездичные+предложения, Erişim Tarihi: 15.05.2021.

Online IV: http://rusgram.narod.ru/2641-2660.html, Erişim Tarihi: 10.05.2021.

Online V: http://rusgram.narod.ru/2641-2660.html, Erişim Tarihi: 10.05.2021. 
TÜRK BILİMKURGU

EDEBIYATI

VE ARKETIPLER

DR. VELİ UĞUR

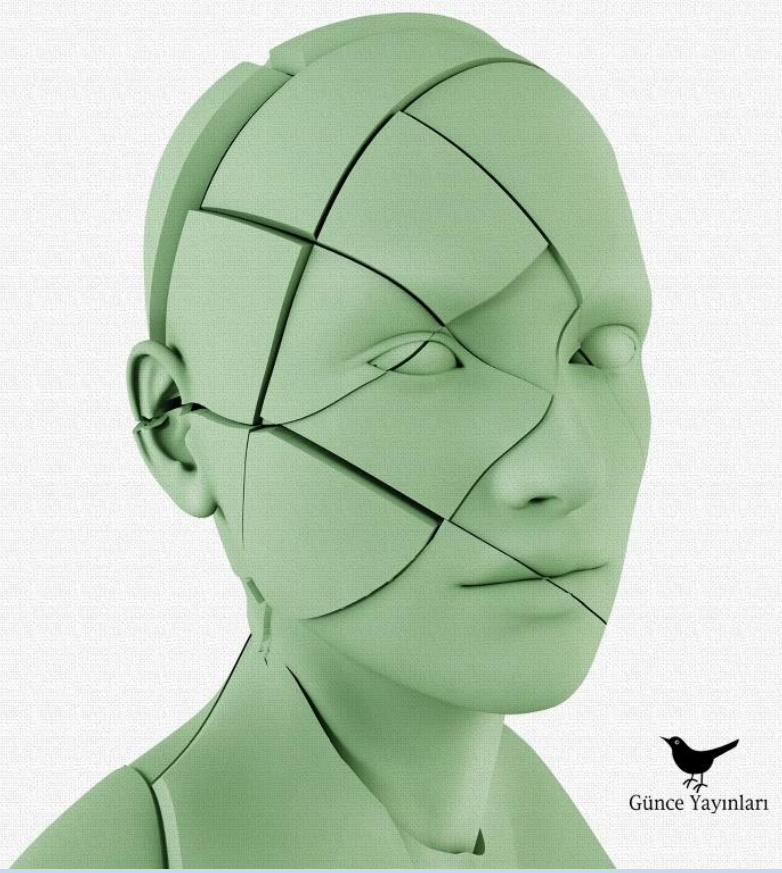

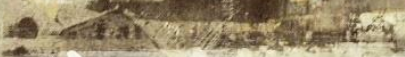

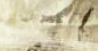

Jktdl| Џill|

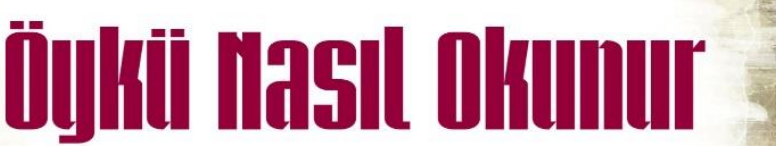

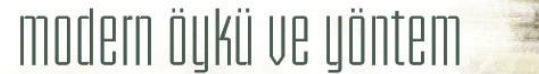

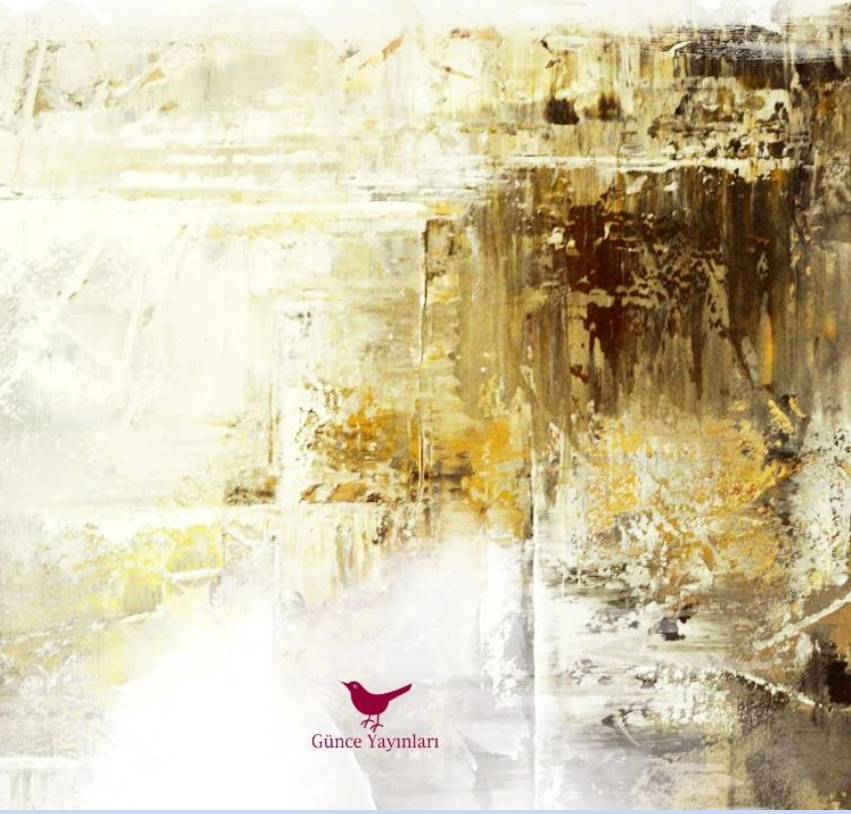

\section{Yazma Sanatı}

Edebivatutn Ebemklusăgu|

Halit Zijya Hilkâyecilliğinde Renklerin Dili

\section{MAKSUT Yit̆̈itBAŞ}

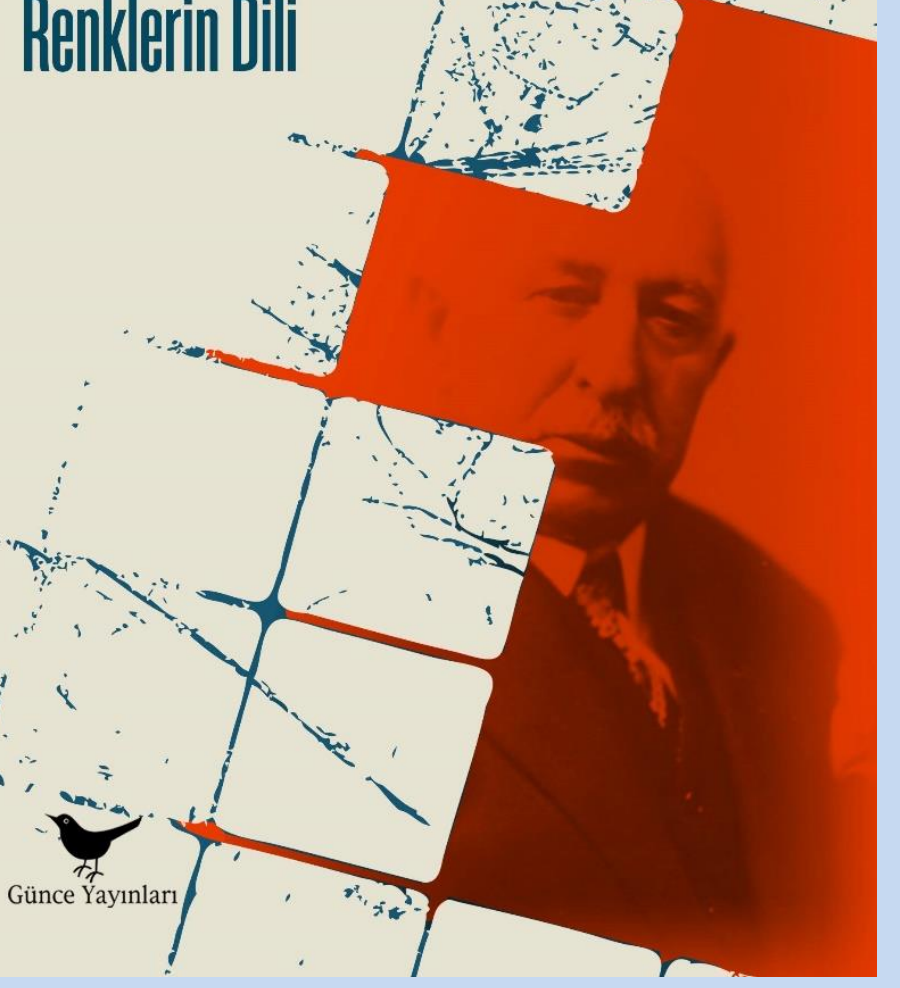

Türkçe Doğru ve Etkili Yazma Teknikleri

Prof. Dr. Önder Göçgün 